\title{
Soil Physico-Bio-Chemical Properties under Poplar + Indian Mustard Inter Cropping System
}

\author{
Tara Bahadur Ghimire* ${ }^{1}$ and Om Prakash Singh Bana ${ }^{2}$ \\ ${ }^{1}$ Seed Science \& Technology Division, NARC, Khumaltar, Nepal \\ ${ }^{2}$ Department of Agronomy, Govind Ballabh Pant University of Agriculture and Technology, Pantnagar, India \\ *Corresponding author: tbghimire2009@gmail.com
}

Received April 2015; Revised June 2015; Accepted June 2015

Scientific Editor: YG Khadka, BK Joshi

Copyright (C) 2015 NARC. Permits unrestricted use, distribution, and reproduction in any medium, provided the original work is properly cited

\begin{abstract}
A field experiment was conducted during the winter seasons of 2008-10 at Agroforestry Research Centre, Pantnagar, India with aim to examine the effect of different levels of recommended Nitrogen $(\mathrm{N})$ : Phosphorus (P): Potassium (K) (NPK) on soil physico-bio-chemical properties under varying poplar tree densities with mustard introcropping. Lower soil bulk density was recorded under 1000 trees/ha density compared to sole crop in both the year. Soil bulk density (BD) decreased underneath trees. However, soil pH, available $\mathrm{N}$ and $\mathrm{K}$ were not influenced by tree density in both the years. Electrical conductivity (EC) and soil organic carbon (SOC) increased underneath trees of either tree density compared to sole crop in both the years. Significantly $(P<0.05)$ higher available P was recorded under 1000 trees/ha density compared to 250 and 500 trees/ha densities including sole crop in 2008-09. Similarly, soil microbial biomass carbon (SMBC) increased with increasing the tree density and significantly $(P<0.01)$ higher value was recorded under 1000 trees/ha density compared to sole crop and sparse density both the years except 2009-10, where 500 and 1000 trees/ha densities remain statistically at par. On the other hand, dehydrogenase activity (DA) was maximum under 500 trees/ha density compared to sole crop and 1000 trees/ha density in both the years. Among the fertility levels, the maximum SOC and available N were recorded with 75\% compared to 50, 100 and 125\% of recommended NPK in 2008-09, except available N with $100 \%$ of recommended NPK. But, available P was more with $100 \%$ of recommended NPK in 2008-09. Similarly, maximum SMBC were recorded with 75 \% compared to higher doses of recommended NPK in both the years. Similarly, BD, EC, SOC, available N, P and K were recorded maximum and soil $\mathrm{pH}$ minimum in 0-15 cm soil layers compared deeper layers.
\end{abstract}

Key words: Fertility levels, pH, available N, P and K, DA

\section{सारांश}

माटोको भौतिक, जैविक तथा रसायनिक गुणमा विभिन्न सिफारिश मात्राको नाइट्रोजन, फास्फोरस तथा पोटासको लहरे पीपलका बिभिन्न घनत्व र खुला स्थानमा परीक्षण गर्ने उद्देश्यले सन् २००६ देखी २०१० को हिउँदे सिजनमा तेलबाली लगाई गोविन्दवल्लभ पंत कृषि तथा प्रोद्योगिकी विश्वविद्यालय, भारतको कृषि वन अनुसन्धान केन्द्र, पथ्थर चट्टामा परीक्षण संचालन गरिएको थियो । माटोको खदिलोपन (स्वायल बल्क डेन्सिटी) लहरे पिपलका रुखहरु मुनि घटेको र १००० रुख प्रति हेक्टर लगाइएको खेतमा रुख नभएको खाली खेत (एकलबाली) को तुलनामा तात्विक रुपमा दुवै वर्ष कम मापन गरिएको थियो। यद्यपि माटोको अम्लियपन, उपलब्ध नाइट्रोजन तथा पोटासियमको मात्रा दुवै वर्षमा विभिन्न घनत्वका रुखले प्रभावित पारेको पाईएन । विधुतिय चालकता (इलेट्रीकल कन्डकटिभिटी) तथा माटोको जैविक कार्बन दुवैवर्ष सबै घनत्वका रुखहरु मुनि खाली खेतको तुलनामा बढेको पाइयो। सन् २००६ र ०९ मा माटोको उपलब्ध फास्फोरसको मात्रा १००० रुख प्रति हेक्टरको घनत्वमा २५० र पू० रुख प्रति हेक्टर र खाली खेत भन्दा तात्विकरुपले बढ़ी मापन गरियो। त्यसैगरी, माटोको सुक्ष्म जिवाणुहरुको जैविककार्वन (स्वायल माइक्रोवियल बायोमास कार्बन) लहरे पिपल रुखका घनत्वहरु बढदै जाँदा बढेको पाइयो र खाली खेत र पातलो घनत्व भएका रुखहरुको खेतमा भन्दा १००० रुख प्रति हेक्टर भएको खेतमा बढी मापन गरियो। अर्को तर्फ दुवै वर्ष डिहाड्रोजेनेज एक्टीभिटी (इनजाइमेटिक गतिविधि) पू०० रुख प्रति हेक्टर घनत्व भएको खेतमा, खाली खेत र १००० रुख प्रति हेक्टर भएको खेतमा भन्दा बढ़ी रहेको पाइयो । २००६ र ०९ मा सबभन्दा बढी माटोको प्राड़ारिक कार्बन र उपलब्ध नाइट्रोजनको मात्रा पू०, १०० र १२५ू भन्दा अपू सिफारिश मात्राको नाइट्रोजन, फास्फोरस, पोटासियम प्रयोग गरेको खेतमा पाइयो। तर, २००६ र ०९ मा उपलब्ध फास्फोरस १००४ सिफारिस मात्राको नाइट्रोजन, फास्फोरस, पोटासियम प्रति हेक्टर दिएको खेतमा बढी मापन गरियो। त्यसै गरी, माटोको सूक्ष्म जैविककार्वन पदार्थ उच्च मात्रामा भन्दा ७ूू सिफारिश मात्राको नाइट्रोजन, फास्फोरस, पोटासियम प्रति हेक्टर दिएको खेतमा दुवै वर्ष बढी मापन गरियो । माटोको घनत्व, बिधुतिय चालकता, माटोको जैविक कार्बन, उपलब्ध नाइट्रोजन, फास्फोरस, पोटासियम जस्ता परिवर्त्यहरु (Variables) माथिल्लो सतहको माटो (O-१५ से.मी.) मा तल्लो सतहको माटोमा भन्दा बढ़ी मापन गरियो भने माटोको अम्लियपना माथिल्लो सतहमा कम रहेको पाइयो।

\section{INTRODUCTION}

Soil fertility deterioration, in general, and organic matter depletion in particular under intensive agriculture system are the main problems in the tropical and sub-tropical region of Indian sub-continent. To certain extent agro-forestry land use system could be an alternate to reduce land degradation. Recently, Chauhan et al (2010) suggested Poplar (Populus deltoides Bartr) based agro-forestry as one of the viable land use options to prevent land degradation by which biological production could be restored sustainably. This system has been quite popular in northern India with expanding coverage every year. In such a system organic carbon content in soil (0-15 $\mathrm{cm})$ has been shown to increased by $35.6 \%$ after 6 years of poplar planting than in land having single wheat crop (Chauhan et al 2010). As such, substantial loss in wheat yield occurred under Poplar, but compensated by the trees in terms of biomass, economics and carbon mitigation potential. There is need to increase the level of soil organic carbon not only to maintain land productivity, but also to provide a sink for atmosphere $\mathrm{CO}_{2}$ in the terrestrial carbon pool. Moreover, the deposition of Poplar leaf litter changes C:N (Carbon:Nitrogen) ratio of the soil compensating potential crop growth.

The leaf litter biomass may vary depending on the tree age, density and management, hence nutrient cycling may also vary because soil biological activities are influenced by trees canopy, thereby availability of nutrients to underneath crops (Pingale 2009). The graded levels of fertilizers applied in inter cropping system invariably used by both crop as well as trees in agri-silvicultural system (Prasadini and Sreemannarayana 2007). However, such knowledge has rarely been examined in specific agri-silviculture system. Therefore, the present paper attempt to provide empirical knowledge on residual effect in soil in terms of physical, chemical and biological properties having varying Poplar tree density underneath Indian mustard with various levels of fertilizers applied. 


\section{MATERIALS AND METHODS}

The field experiments were conducted at Agroforestry Research Centre Patharchatta of Govind Bhallav Pant University of Agriculture and Technology, Pantnagar, Uttarakhand located at $29^{\circ} \mathrm{N}$ Latitude, $79.3^{0} \mathrm{E}$ Longitude and at an altitude of $243.84 \mathrm{~m}$ above mean sea level during 2008-09 and 2009-10. The Poplar clone G4 were planted during February 2000 and mortality was maintained by gap-filling in following year to maintain 16 trees in each density at five meter row distance. The soil of the experiment site was clay loam (0-15 $\mathrm{cm}$ ) in texture, having $\mathrm{pH}$ 8.0-8.05, organic carbon 0.99-1.17\%, available nitrogen $(\mathrm{N})$ 143.3-141.4 kg/ha, available phosphorus (P) $11.7-12.7 \mathrm{~kg} / \mathrm{ha}$ and available potassium (K) $133.9-136.7 \mathrm{~kg} / \mathrm{ha}$ in 0 to $45 \mathrm{~cm}$ soil layer under treeless (sole crop) to $1000 / \mathrm{ha}$ tree density plots. The land was thoroughly ploughed and incorporated leaf litter into the soil two weeks before sowing. Upland rice and wheat cropping sequence were followed till the beginning of the present experiment. The field remained fallow between the two experiments in kharif seasons of 2008-09 and 2009/10. The experiment was laid out in split-plot design taking four tree densities, i.e. Sole crop (open), 250, 500 and 1000 trees/ha plots with four fertility viz. 50\%, 75\%, 100\% and 125\% of recommended dose of fertilizer (RDF) for Indian mustard (Brassica juncea L.) as sub-plot treatment with four replications. The recommended fertilizer dose was $120 \mathrm{~kg} \mathrm{~N}, 40 \mathrm{~kg}$ $\mathrm{P}_{2} \mathrm{O}_{5}$ and $20 \mathrm{~kg} \mathrm{~K} 2 \mathrm{O} / \mathrm{ha}$. The NPK mixture (12:32:16) and urea (46\% N) were used as a source of fertilizers in both the years. The doses of $50 \% \mathrm{~N}$ and $100 \% \mathrm{P}$ and $\mathrm{K}$ for Indian mustard were applied into the soil at the time of sowing.

Indian mustard var. Kranti was inter-cropped on $8^{\text {th }}$ Nov in 2008 and $7^{\text {th }}$ Nov in 2009. The mustard seed was sown in lines $30 \mathrm{~cm}$ apart continuously keeping seed rate @ 5 kg/ha manually. The crop was irrigated only once with tube well water in both years at about 45 days after sowing (DAS). The remaining $50 \% \mathrm{~N}$ was top dressed after one week of irrigation. The crop was harvested on March $23^{\text {rd }}$ and $26^{\text {th }}$, in 2009 and 2010 , respectively when more than $80 \%$ pod turned yellow. Soil samples from each main plot in $0-15$, $15-30$ and $30-45$ $\mathrm{cm}$ depths were collected before sowing and after harvest of mustard crop in both the years for assessing chemical properties viz. $\mathrm{pH}$, Electrical Conductivity (EC), Soil Organic Carbon and available N, P and K.

-For soil microbial study, samples from each subplot at 0-15 cm soil depth were collected at peak flowering stage and stored in deep freeze for the determination of soil microbial biomass carbon and dehydrogenase activity. Bulk density was determined by Core sampler from each main plot at 0-15, 15-30 and 30-45 cm soil depths before sowing mustard crop. Soil samples were analyzed for pH (Jackson 1973), EC, SOC (Black 1965), available N (Subbiah and Asija 1956), P (Olsen et al 1954) and K (Jackson 1973) using standard procedures. The soil values of $\mathrm{pH}, \mathrm{EC}$, SOC, available N, P and K were determined depth wise in 0-15, 15-30 and 30-45 cm depths. Chloroform fumigation extraction (Jenkinson and Powlson 1976) and TTC assay method (Tabatabai 1994) were employed for the determination of soil microbial biomass carbon (SMBC) and dehydrogenase activity (DA), respectively.

\section{RESULTS}

\section{Soil Physical Properties}

\section{Soil Bulk Density}

The soil bulk density (BD) (g/cc) was influenced by tree density and soil depths in both the years, respectively. The soil bulk density decreased with increasing tree density (Table 1). The highest $1.498 \mathrm{~g} / \mathrm{cc}$ soil bulk density was recorded in sole cropping (open plot) as compared to underneath trees density in 2008-09 and 2009-10, respectively. However, the differences in soil bulk density between 250 and 500, and 500 and 1000 trees/ha plots in first year; and amongst 250, 500 and 1000 trees/ha densities in the second year were insignificant. The soil bulk density increased with increase in the soil depth. However, $15-30 \mathrm{~cm}$ soil depth had significantly $(\mathrm{P}<0.05)$ higher bulk density than 0-15 cm in 2009-10 (Table 1).

\section{Soil Chemical Properties}

\section{Soil $\mathrm{pH}$}

The soil pH after harvest of mustard crop was not influenced by tree density and fertility levels both during 2008-09 and 2009-10, while the soil $\mathrm{pH}$ varied with soil depths in both the years (Table 2). The soil $\mathrm{pH}$ increased with increasing the soil depth up to $30 \mathrm{~cm}$ and declined in further deeper (30-45 cm). The higher (8.04 and 8.47) and lower (7.80 and 8.23) soil pH was observed in 15-30 and 0-15 cm soil depths, respectively in both the years.

\section{EC of Soil}

The EC (dS/m) of extract from saturated soil after harvest of mustard crop was influenced by tree density, fertility levels and soil depths in both the years (Table 2). The EC of soil increased with increased tree density. The maximum $(0.610$ and $0.508 \mathrm{dS} / \mathrm{m})$ substantially higher EC was recorded under 500 trees/ha density in 2008-09 and under 1000 trees/ha density in 2009-10, respectively, as compared to sole crop (open plot) and 250 trees/ha density in 2008-09. EC was similar in open plot and sparse density (250 trees/ha) in first year and higher density in second year. Moreover, EC of soil underneath poplar trees was more compare to sole crop (open plot) in both the years. Among the fertility levels, the maximum $(0.678$ and $0.480 \mathrm{dS} / \mathrm{m})$ EC was recorded with $50 \%$ compared to 75 , 100 and $125 \%$ of recommended NPK in first year and with $100 \%$ compared to 75 and $125 \%$ of recommended NPK in second year, respectively. Whereas, the differences between 50 and $100 \%$ and 75 and 125\% of recommended NPK in 2009-10 were not significant. The EC of soil decreased with increasing soil depth and the maximum $(0.588 \mathrm{dS} / \mathrm{m})$ EC was recorded in $0-15 \mathrm{~cm}$ depth comparing to $15-30$ and $30-45$ cm layers in 2008-09 and 2009-10. However, the EC in 15-30 and 30-45 cm soil depths were almost similar in 2009-10. 
Table 1. Soil bulk density as influenced by poplar tree density and varying soil depths

\begin{tabular}{llc}
\hline Treatment & \multicolumn{1}{c}{ Bulk density (g/cc) } \\
\hline A. Tree density (trees/ha) & $\mathbf{2 0 0 8 - 0 9}$ & $\mathbf{2 0 0 9 - 1 0}$ \\
\hline Sole crop & 1.402 & 1.498 \\
250 & 1.328 & 1.389 \\
500 & 1.313 & 1.389 \\
1000 & 1.295 & 1.375 \\
SEm \pm & 0.009 & 0.024 \\
CD, $5 \%$ & 0.030 & 0.078 \\
\hline B. Soil depth (cm) & & \\
\hline $0-15$ & 1.290 & 1.293 \\
$15-30$ & 1.366 & 1.414 \\
$30-45$ & 1.349 & 1.531 \\
SEm \pm & 0.008 & 0.023 \\
CD, $5 \%$ & 0.024 & 0.069 \\
\hline
\end{tabular}

\section{Organic Carbon (OC) Content in Soil}

The organic carbon (\%) of soil after harvest of mustard crop was influenced by tree density, fertility levels and soil depths in both the years, except by fertility levels in 2009-10 (Table 2). The SOC (\%) increased with increasing tree densities having maximum values 1.11 and 1.01\% in 2008-09 and 2009-10, respectively. The highest OC was recorded under highest density (1000 trees/ha) in both years, compared to sole crop field. The differences between sole crop and 250 trees/ha and amongst 250, 500 and 1000 trees/ha densities in first year and 250, 500 and 1000 trees/ha densities in second year were somewhat closer. The SOC increased by 11 and $25 \%$; 15 and $26 \%$ and 19 and 26\% with each successive increase in tree densities from zero to 1000/ha in 2008-09 and 2009-10, respectively.

Among the fertility levels, the maximum (1.11\%) soil OC was recorded with 75\% of recommended NPK compared to 50 , 100 and 125 $\%$ in 2008-09. The differences between 50, 100 and 125\% of recommended NPK were not substantial with respect to SOC content in soil. Organic carbon of soil decreased with increasing soil depth having maximum (1.41\%) recorded in 0-15 cm depth comparing to 15 30 and 30-45 cm depths in both years. However, 15-30 cm depth had higher SOC than 30-45 cm in both the years. Surface soil layer (0$15 \mathrm{~cm}$ ) showed approximately two times (107 and 133\%) more SOC. Whereas, the middle soil layer (15-30 cm) contained 53 and $45 \%$ more SOC than the lower most studied layer i.e. $30-45 \mathrm{~cm}$.

\section{Available Nitrogen in Soil}

The available $\mathrm{N}$ in soil after harvest of mustard crop was not influenced by tree density in both the years, while fertility levels showed substantial effect only in 2008-09 and by soil depths in both the years (Table 3). The maximum (178.1 kg/ha) more soil available $\mathrm{N}$ was recorded with $75 \%$ as compared to 50 and 125\% of recommended NPK in 2008-09. The differences between 50 and 100 ; 50 and 125 and 75 with $100 \%$ of recommended NPK were not substantial. The available $\mathrm{N}$ in soil decreased with increasing soil depths having the maximum (197.3 kg/ha) high soil available $\mathrm{N}$ at $0-15 \mathrm{~cm}$ depth in both years, comparing to 15-30 and 30-45 cm depths. At 15-30 cm depth higher available $\mathrm{N}$ compared to $30-45 \mathrm{~cm}$ depth occurred in both years. The maximum available $\mathrm{N}$ (kg/ha) was found in surface (0-15 $\mathrm{cm}$ ) layer during both the years. The lowest available $\mathrm{N}$ was recorded in the lower most soil of $30-45 \mathrm{~cm}$.

\section{Available Phosphorus in Soil}

The available $P$ in the soil was significantly influenced both by tree density $(P<0.05)$ and fertility levels $(P<0.01)$ only in $2008-09$, but by soil depths in both the years (Table 3$)$. The maximum P $(19.5 \mathrm{~kg} / \mathrm{ha}$ ) was occurred under 1000 trees per ha density compared to other densities including sole crop plots in year 2008-09. The differences amongst sole crop plots and under 250 and 500 trees/ha densities remained statistically non-significant $(P<0.05)$. The available $\mathrm{P}$ in soil increased with increasing fertility levels up to $100 \%$ of recommended NPK, while the difference between 75 and $125 \%$ of recommended NPK was not significant.

\section{Available Potassium (K) in Soil}

The available $\mathrm{K}$ in soil after harvest of mustard crop was not influenced by tree density and fertility levels in any of the growing season, but varied with the soil depths in both the years (Table 3). Alike available $\mathrm{N}$ and $\mathrm{P}$, available $\mathrm{K}$ in soil also decreased with increased soil depths. The maximum (200.9 and $224.5 \mathrm{~kg} / \mathrm{ha}$ ) available $\mathrm{K}$ in soil was recorded in $0-15 \mathrm{~cm}$ depth which decreased significantly $(\mathrm{P}<0.05)$ with soil depth both years due to more turn-over of organic residues on the surface soil. The lowest available K was recorded in the lower most soil layer of $30-45 \mathrm{~cm}$.

\section{Soil Biological Properties}

\section{Soil Microbial Biomass Carbon}

Soil microbial biomass carbon $(\mathrm{SMBC})$ was significantly $(\mathrm{P}<0.05)$ influenced by tree density and fertility levels in both the years $($ Table 4). SMBC increased with high tree densities having maximum (239.0 $\mu_{\mathrm{g} \mathrm{g}} \mathrm{g}^{-1}$ soil), higher SMBC under highest (i.e. 1000 trees/ha) density both in 2008-09 and 2009-10, respectively, comparing other densities including sole crop in first year and sole crop and 250 trees/ha density in second year. The differences between 250 and 500 trees/ha and 500 and 1000 trees/ha densities were not significant $(\mathrm{P}<0.05)$ in 2009-10. Among the fertility levels, the maximum $227.88 \mu \mathrm{g} \mathrm{g}^{-1}$ soil was significantly $(\mathrm{P}<0.05)$ higher in $75 \%$ of 
recommended NPK, respectively, compared to 100 and 125\% of recommended NPK both in 2008-09 and 2009-10. The differences between 50 and $75 \%$ and 100 and $125 \%$ of recommended NPK were not significant $(\mathrm{P}<0.05)$ in both the years.

Table 2. pH, EC and OC (\%) of soil as influenced by poplar tree density, fertility levels and soil depths after harvest of mustard crop during both the growing seasons

\begin{tabular}{|c|c|c|c|c|c|c|}
\hline \multirow[t]{2}{*}{ Treatment } & \multicolumn{2}{|c|}{ pH } & \multicolumn{2}{|c|}{ EC $(d S / m)$} & \multicolumn{2}{|c|}{ SOC (\%) } \\
\hline & 2008-09 & 2009-10 & 2008-09 & 2009-10 & 2008-09 & 2009-10 \\
\hline \multicolumn{7}{|c|}{ A. Tree density (trees/ha) } \\
\hline Sole crop & 7.98 & 8.40 & 0.425 & 0.322 & 0.93 & 0.80 \\
\hline 250 & 7.90 & 8.33 & 0.456 & 0.503 & 1.03 & 1.00 \\
\hline 500 & 7.96 & 8.41 & 0.610 & 0.500 & 1.07 & 1.01 \\
\hline 1000 & 7.93 & 8.36 & 0.587 & 0.508 & 1.11 & 1.01 \\
\hline $\mathrm{SEm} \pm$ & 0.03 & 0.03 & 0.014 & 0.011 & 0.03 & 0.04 \\
\hline CD, $5 \%$ & NS & NS & 0.051 & 0.040 & 0.12 & 0.16 \\
\hline \multicolumn{7}{|c|}{ B. Fertility levels (\% of recommended NPK) } \\
\hline 50 & 7.93 & 8.36 & 0.678 & 0.466 & 1.02 & 0.96 \\
\hline 75 & 7.93 & 8.38 & 0.431 & 0.452 & 1.11 & 0.91 \\
\hline 100 & 7.96 & 8.39 & 0.468 & 0.480 & 1.00 & 0.98 \\
\hline 125 & 7.96 & 8.37 & 0.500 & 0.434 & 1.01 & 0.97 \\
\hline SEm \pm & 0.02 & 0.02 & 0.010 & 0.009 & 0.01 & 0.02 \\
\hline CD, $5 \%$ & NS & NS & 0.030 & 0.026 & 0.04 & NS \\
\hline \multicolumn{7}{|c|}{ C. Soil depth (cm) } \\
\hline $0-15$ & 7.80 & 8.23 & 0.588 & 0.487 & 1.41 & 1.40 \\
\hline $15-30$ & 8.04 & 8.47 & 0.530 & 0.441 & 1.04 & 0.87 \\
\hline $30-45$ & 7.98 & 8.42 & 0.441 & 0.447 & 0.68 & 0.60 \\
\hline $\mathrm{SEm} \pm$ & 0.01 & 0.01 & 0.005 & 0.005 & 0.005 & 0.01 \\
\hline CD, $5 \%$ & 0.03 & 0.04 & 0.014 & 0.015 & 0.01 & 0.03 \\
\hline
\end{tabular}

Table 3. Available N, P and $\mathrm{K}$ in soil (kg/ha) as influenced by various poplar tree densities, fertility levels and soil depths after harvest of mustard crop during both the growing seasons

\begin{tabular}{|c|c|c|c|c|c|c|}
\hline \multirow[t]{2}{*}{ Treatments } & \multicolumn{2}{|l|}{ Nitrogen } & \multicolumn{2}{|c|}{ Phosphorus } & \multicolumn{2}{|c|}{ Potassium } \\
\hline & 2008-09 & 2009-10 & 2008-09 & 2009-10 & 2008-09 & 2009-10 \\
\hline \multicolumn{7}{|c|}{ A. Tree density(trees/ha) } \\
\hline Sole crop & 175.5 & 159.7 & 14.5 & 19.0 & 131.8 & 145.0 \\
\hline 250 & 175.2 & 169.5 & 15.3 & 19.0 & 158.3 & 158.3 \\
\hline 500 & 155.1 & 162.4 & 14.7 & 18.7 & 129.2 & 159.0 \\
\hline 1000 & 155.9 & 163.8 & 19.5 & 18.8 & 143.2 & 151.7 \\
\hline SEm \pm & 7.9 & 3.2 & 1.0 & 0.6 & 12.6 & 16.6 \\
\hline $\mathrm{CD}, 5 \%$ & NS & NS & 3.4 & NS & NS & NS \\
\hline \multicolumn{7}{|c|}{ B. Fertility levels(\% of recommended NPK) } \\
\hline 50 & 158.4 & 160.9 & 13.2 & 18.0 & 140.5 & 150.4 \\
\hline 75 & 178.1 & 164.3 & 15.8 & 19.6 & 142.5 & 147.0 \\
\hline 100 & 173.6 & 164.3 & 18.4 & 19.7 & 138.7 & 159.4 \\
\hline 125 & 151.5 & 165.9 & 16.6 & 18.3 & 140.8 & 157.2 \\
\hline $\mathrm{SEm} \pm$ & 5.7 & 1.8 & 0.5 & 0.6 & 4.3 & 6.3 \\
\hline $\mathrm{CD}, 5 \%$ & 16.6 & NS & 1.5 & NS & NS & NS \\
\hline \multicolumn{7}{|c|}{ C. Soil depth (cm) } \\
\hline $0-15$ & 197.3 & 191.8 & 26.9 & 27.2 & 200.9 & 224.5 \\
\hline $15-30$ & 161.7 & 161.9 & 12.8 & 15.7 & 117.1 & 143.1 \\
\hline $30-45$ & 137.2 & 137.9 & 8.3 & 13.8 & 103.9 & 92.9 \\
\hline $\mathrm{SEm} \pm$ & 3.1 & 1.3 & 0.3 & 0.5 & 3.1 & 3.6 \\
\hline CD, 5\% & 8.9 & 3.7 & 1.0 & 1.6 & 8.6 & 10.1 \\
\hline
\end{tabular}

NS- Not significant

\section{Dehydrogenase Activity}

Dehydrogenase activity was significantly $(\mathrm{P}<0.05)$ influenced by tree density during both the years. The dehydrogenase activity was not influenced by fertility levels during both the years (Table 4). Dehydrogenase activity increased with increased tree densities and reached maximum (118 and $\left.167 \mu \mathrm{g} \mathrm{TPFg}^{-1} 24 \mathrm{hr}^{-1}\right)$ and significantly $(\mathrm{P}<0.05)$ higher under 500 trees/ha density in 2008-09 and 200910, respectively, compared to sole crop in first year and sole crop, 250 and 1000 trees/ha densities in second year. The differences between sole crop and 1000 trees/ha and amongst 250, 500 and 1000 trees/ha in 2008-09 and between 250 and 1000 trees/ha densities in 2009-10 were not significant $(\mathrm{P}<0.05)$. 


\section{DISCUSSION}

The soil bulk density (BD) (g/cc) was substantially influenced by tree density and soil depths in both the years i.e. 2008-09 and 2009-10 (Table 1). The lower bulk density was recorded in higher density due to high organic matter content in closely spaced tree density. More leaf litter fall might occurred in plots under higher tree densities. Higher value of bulk density was observed in second year due to removal of leaf litter in first year from the mustard plot for establishment and proper growth of experimental crop (mustard), hence complete addition of litter to soil could not be allowed. These results are in close agreement with Nayak et al (2009) and Pingale, (2009). Nayak et al (2009) observed the lower bulk density under Prosopis juliflora tree as compared to open field. Pingale (2009) also observed decrease in soil bulk density with increased in Populus deltoides tree density. The soil bulk density increased with the increase in the soil depth due to poor organic matter content at deeper depth. Gupta and Sharma (2008) also reported soil physical properties such as porosity, density and water holding capacity improved in poplar plantation compared to sole crop in Uttrakhand.

The soil $\mathrm{pH}$ varied with soil depths in both the years (Table 2). The marginally lower $\mathrm{pH}$ in 0-15 cm soil depth under agroforestry systems may be due to substantial addition of organic matter to the surface soil under trees and organic acid released during litter decomposition as also reported in agrisilvicultural system by Prasadini and Sreemannarayana (2007) and Kumar et al (2008). Newaj et al (2007) also observed very nominal changes in soil pH under White siris (Albizia procera) based agrisilvicultural system after 4 years of experimentation as compared to initial value due to very high free calcium carbonate content in the soils. Bharadwaj et al (2001) observed increasing trend of soil $\mathrm{pH}$ with deeper soil layers under various tree densities of poplar.

EC of soil underneath poplar trees was higher compared to sole crop (open) in both the years (Table 2). Newaj et al (2007) also observed higher EC under Albizia procera based agrisilvicultural system than under pure crop of mustard and black gram. This could be due to enrichment of soil mineral basic salts through addition and decomposition of litter. Singh et al (2007) reported that poplar trees returns maximum amount of Ca into the soil through litter fall amongst different macronutrients.

Among the fertility levels, lower (50\%) of NPK fertilized plots showed higher value of EC. Maji and Mandal (2004) also observed that addition of $75 \%$ of recommended NPK plus FYM either in both the seasons and single season enhanced the electrical conductivity of soil than the control in paddy-oat/berseem rotations. The EC of soil decreased with increasing soil depth. Higher magnitude of EC in 0$15 \mathrm{~cm}$ depth compared to lower depth occurred probably due to the presence of more litter at the surface soil. Similar results have also been shown by Newaj et al (2007) in agrisilviculture system in semi-arid areas of India.

Soil organic carbon contents decreased in 2009-10 compared to 2008-09, this might bedue to defoliation of poplar leaves by insect (caterpillar) attack during early autumn season in 2009-10. It is speculated that the defoliation must have reduced the total biomass of organic matter addition into the soil in 2009-10. Such facts might need to be examined in future studies how the caterpillars might impact the biomass loss on soil organic carbon deposits. The SOC (\%) in soil increased with increasing the tree densities compared to sole crop i.e. open field. The SOC (\%) increased by 11 and 25\%; 15 and 26\% and 19 and 26\% with each successive increase in tree density from zero to 1000/ha in 2008-09 and 2009-10, respectively. Previous studies have also argued that continuous litter addition and tree shading should helped in protecting soil organic matter by reducing oxidation (Gill and Burman 2002, Bharadwaj et al 2001, Pingale 2009). Swami and Puri (2005) also observed 15.1\% increase over initial value in SOC (\%) in Gmelina arborea based agrisilvicultural system, while it has been $51.2 \%$ increase in pure plantation of G. arborea.

Among the fertility levels, the maximum soil OC was recorded with 75\% of recommended NPK compared to other levels of NPK. Das et al (2010) also observed highest soil organic carbon content with lower recommended NPK (50\% NPK) in conjunction with Azolla compost compared to recommended NPK levels. Moscatelli et al (2008) observed fertilization did not modify soil capacity to accumulate organic matter in the medium term. Organic carbon of soil decreased with increasing soil depth and the maximum SOC was recorded in upper layer compared to deeper layers. Surface soil layer $(0-15 \mathrm{~cm})$ showed approximately two times $(107$ and $133 \%)$ more SOC (\%) during 2008-09 and 2009-10, respectively. Whereas, the middle soil layer $(15-30 \mathrm{~cm})$ contained 53 and $45 \%$ more SOC (\%) than the lower most layer i.e. 30-45 cm during 2008-09 and 2009-10, respectively. Similar variations in SOC with soil depth have also been indicated by Pingale (2009), Swami and Puri (2005) and Chauhan et al (2010).

The maximum soil available N was recorded with 75\% compared to lower (50\%) and higher levels (125\%) of NPK. This may be due to depressive effect of higher dose of $\mathrm{P}$ on nitrogen availability in the soil. Haris et al (1999) had observed the depressed available $\mathrm{N}$ status of soils by application of $\mathrm{P}$. The available $\mathrm{N}, \mathrm{P}$ and $\mathrm{K}$ in soil decreased with increased soil depths and the maximum available $\mathrm{N}, \mathrm{P}$ and $\mathrm{K}$ $(\mathrm{kg} / \mathrm{ha})$ was found in surface soil $(0-15 \mathrm{~cm})$ layer during both the years due to more turn-over of organic residues on the surface soil. The lowest available N, P and K was recorded in the lower most soil layer of 30-45 cm. Bharadwaj et al (2001) also observed decreasing trend in available $\mathrm{N}, \mathrm{P}$ and $\mathrm{K}$ content with increase in soil depth even under high density poplar plantation.

Similarly, Swami et al (2008) also observed available nutrient (NPK) decreased with soil depth under Gmelina arborea based agrisilvicultural system. Maximum available P was recorded under highest (1000/ha) tree density probably due to the high organic matter content in the soils. The decomposition of organic matter is accompanied by the release of appreciable quantities of carbon dioxide which forms carbonic acid, when dissolved in water can decompose certain primary minerals. It has been shown that in calcareous soils, carbon dioxide production plays an important role in increasing the phosphate availability. The organic material forms a cover on sesquioxide and reduces the phosphate fixing capacity of the soil (Das et al 2010). The maximum available $\mathrm{P}$ in soil was obtained with $100 \%$ NPK probably due to the P content of soil increased with increased dose of NPK. 
Table 4. Soil microbial biomass carbon $\left(\mu \mathrm{g} \mathrm{g}^{-1}\right)$ and dehydrogenase activity ( $\mu \mathrm{g} \mathrm{TPF} \mathrm{g}^{-1} 24 \mathrm{~h}^{-1}$ ) as influenced by poplar tree density and fertility levels at flowering stage during both the growing seasons

\begin{tabular}{|c|c|c|c|c|}
\hline \multirow[t]{2}{*}{ Treatments } & \multicolumn{2}{|c|}{ Soil microbial biomass carbon } & \multicolumn{2}{|c|}{ Dehydrogenase activity } \\
\hline & 2008-09 & $2009-10$ & 2008-09 & 2009-10 \\
\hline \multicolumn{5}{|c|}{ A. Tree density(trees/ha) } \\
\hline Sole crop & 159.00 & 187.00 & 103.00 & 127.00 \\
\hline 250 & 179.00 & 207.00 & 117.00 & 147.00 \\
\hline 500 & 205.00 & 224.00 & 118.00 & 167.00 \\
\hline 1000 & 226.00 & 239.00 & 109.00 & 145.00 \\
\hline $\mathrm{SEm} \pm$ & 6.04 & 6.01 & 3.49 & 5.09 \\
\hline $\mathrm{CD}, 5 \%$ & 19.31 & 19.22 & 11.15 & 16.28 \\
\hline \multicolumn{5}{|c|}{ B. Fertility levels (\% of recommended NPK) } \\
\hline 50 & 197.73 & 219.70 & 113.03 & 141.80 \\
\hline 75 & 203.10 & 227.88 & 112.98 & 150.70 \\
\hline 100 & 185.41 & 205.29 & 111.39 & 153.40 \\
\hline 125 & 180.82 & 203.35 & 109.79 & 140.60 \\
\hline $\mathrm{SEm} \pm$ & 3.40 & 3.43 & 1.12 & 4.09 \\
\hline CD, $5 \%$ & 9.75 & 9.83 & NS & NS \\
\hline
\end{tabular}

NS=Not significant

Soil microbial biomass carbon increased with increased tree densities owing to higher organic carbon content, and favorable microclimate under higher density. Kumar et al (2008) also observed higher microbial activity under plantations of different tree species in the upper surface of soil due to presence of higher organic carbon content. Chander et al (1995) observed improved microbial biomass carbon during decomposition of poplar leaf litter compared to Eucalyptus leaf litter.

Higher SMBC was obtained with 75\% of recommended NPK due to adverse effect of higher dose of chemical fertilizers on active microbial population growth. This finding is similar to Cheema et al (2008) where enzymatic activity in soils was found to be depressed with continuous application of recommended inorganic fertilizers. Dehydrogenase activity increased with increased tree densities and reached maximum under 500 trees/ha density. This was probably due to higher fine root biomass under 500/ha tree density. Since the roots are known to produce exudates which are likely to provide energy for microbial metabolic activity. Singh and Singh (1994) also observed fine roots biomass of poplar was more in wider spacing, generally in $0-15 \mathrm{~cm}$ soil layers. The dehydrogenase activity improved underneath trees comparing to sole crop in both the years indicating increased active microbial population, as it provides correlative information on the biological activity and microbial population in the soil. This improvement in dehydrogenase activity might be due to improved physico-chemical properties of soil by trees. Batra (2004) also observed the dehydrogenase activity of soil being influenced both by the soil physico-chemical characteristics and agricultural management practices.

Agroforestry land use system is viable for sustainable agricultural production due to substantial addition of organic matter into the soil. The soil quality in enhanced underneath trees and optimum tree density is required for proper crop growth under tree canopy. Optimum dose of NPK (75\%) is required for maintaining the soil quality in agrisilviculture system.

Agriculture land is believed to be a major potential sink and could absorb large quantities of carbon, if trees are reintroduced to these systems and judiciously managed together with the crop and/or animals. Thus importance of agroforestry as a land use system is receiving a wider recognition not only in terms of agricultural sustainability, but also due to climate change. Litter fall plays an important role in terms of nutrient cycling, and thus adds to sustainability of the system.

\section{ACKNOWLEDGEMENTS}

We are thankful to GB Pant University of Agriculture and Technology, Pantnagar, Uttrakhand, India for support. Indian Council of Cultural Relation (ICCR), New Delhi is thankful for providing scholarship for pursuing PhD at Pantnagar to Tara B Ghimire.

\section{REFERENCES}

Batra L. 2004. Dehydrogenase activity of normal, saline and alkali soils under different agricultural management systems. J. Indian Soc. Soil Sci. 52(2):160-163.

Bhardwaj SD, P Panwar and S Gautam. 2001. Biomass production potential and nutrient dynamics of Populus deltoides under high density plantations. Indian Forester. 127(2):144-153.

Black CA. 1965. Methods of Soil Analysis. Part 2. American Soc. Agron., Madison, Wisconsin, USA. Pp.1372-1376.

Chander K, S Goyal and KK Kapoor. 1995. Microbial biomass dynamics during the decomposition of leaf litter of poplar and Eucalyptus in a sandy loam. Biol. Fert. Soils. 19(4):357-362.

Chauhan SK, SC Sharma, V Beri, Ritu, S Yadav and N Gupta. 2010. Yield and carbon sequestration potential of wheat (Triticum aestivum)poplar (Populus deltoides) based agri-silvicultural system. Indian J. Agr. Sci. 80 (2): 129-135.

Cheema PS, R Neeraj and HS Baddesha. 2008. Effect of organic farming on microbiological properties in rice-wheat system. Environ. Ecol. 26 (4B):1977-1980.

Das A, DP Patel, GC Munda and PK Ghosh. 2010. Effect of organic and inorganic sources of nutrients on yield, nutrient uptake and soil fertility of maize (Zea mays)-mustard (Brassica campestris) cropping system. Indian J. Agr. Sci. 80(1):85-88.

Gill AS and D Burman. 2002. Production management of field crops in agroforestry systems. In: Recent advances in Agronomy (G Singh, JS Kolar and HS Sekhon, eds). Indian Society of Agronomy, New Delhi. Pp. 523-542. 
Gupta MK and SD Sharma. 2008. Effect of tree plantation on soil properties, profile morphology and productivity index in Uttrakhand. Annals of Forestry. 16(2):209-224.

Haris A, RK Rai, AN Safeena, PK Mukherjee and A Haris. 1999. Available 'N' status of the soil as influenced by phosphorus application and some kharif green manure crops grown in succession with some rabi crops. Ann. Agr. Res. 20 (4): 522-523.

Jackson ML. 1973. Soil Chemical Analysis, Prantice Hall Pvt. Ltd, New Delhi, India.

Jenkinson DS and DS Powlson. 1976. The effects of biological treatments on metabolism in soil. V.A. method for measuring soil biomass. Soil Biol. Biochem. 8:209-213.

Kumar K, R Laik, DK Das and OP Chaturvedi. 2008. Soil microbial biomass and respiration in afforested calciorthent. Indian J. Agrforestry. 10(2):75-83.

Maji NC and SR Mandal. 2004. Effect of long term application of fertilizers and manures on chemical and physical properties of soil. Envron. Ecol. 22(Spl-3):430-434.

Moscatelli MC, A Lagornarsino, PD Angelis and S Grego. 2008. Short and medium term contrasting effects of nitrogen fertilization on C and N cycling in a poplar plantation soil. Forest. Ecol. Manag. 255:447-454.

Nayak AK, U Khan, DK Sharma, VK Mishra, CL Verma, R Singh and G Singh. 2009. Spatial variability of soil physico-chemical properties under Prosopis juliflora and Terminalia arjun in sodic soil of Indo-gangatic plains. J. Indian Soc. Soil Sci. 57 (1): 31-38.

Newaj R, SA Dar, MK Bhargava, RS Yadav and Ajit. 2007. Effect of management practices on growth of white siris grain yield of intercrops, weed population and soil fertility changes in agrisilviculture system in semi-arid India. Indian J. Agr. Sci. 77: 403-407.

Olsen SR, CV Cole and LA Dean. 1954. Estimation of available phosphorus in soil by extraction with sodium carbonate. In: Method of Soil analysis, Part 2. ( CA Black, ed) American Soc. Agron. Inc, Medison, USA. Pp.1044-1046.

Pingale BN. 2009. Studies on Carbon Sequestration in poplar (Populus deltoides Bartr. ex. Marsh) Based Agroforesty System with varying tree density. Master Thesis. GB Pant University of Agriculture \& Technology, Pantnagar -India.

Prasadini P and B Sreemannnarayana. 2007. Impact of agroforestry systems on nutritional status and biological activity on rainfed red sandy loam soils. Indian Forester. 133(11):1519-1525.

Singh B, R Gill and N Kaur. 2007. Litterfall and nutrients return in poplar plantation varying in row directions and spacing. Indian J. Agroforestry. 9(1):33-37.

Singh V and V Singh. 1994. Root distribution in Populus deltoides 'G-3' plantation in the arid region of north-western India. Trop. Ecology. 35 (1):105-113.

Subbiah BV and GL Asija. 1956. A rapid procedure for determination of available nitrogen in rice soils. Current Science. 25:259-260.

Swami SL and S Puri. 2005. Biomass production and C-sequestration of Gmelina arborea in plantation and agroforestry system in India. Agroforest syst. 64 3):181-195.

Swami SL, JK Bharitya and A Mishra. 2008. Growth, biomass, nutrient storage and crop productivity under different tree spacings of Gmelina arborea in agrisilviculture system. Indian J. Agroforestry. 10(2):3-9.

Tabatabai MA. 1994. Soil Enzymes. In: Methods on Soil Analysis. Part 2. Microbiological and Biochemical properties (RW Weavver, S Angle, P Bottomley, D Bezdicek, S Smith, A Tabatabai and A Wollum, eds). SSSA Book series No.5, Soil Science Society of America Inc. Madison, Wisconsin, USA. Pp.775-833. 